\title{
BETWEEN THE HONEY AND THE POISON: CORRUPTION AND ITS PANACEA IN ISLAMIC HERMENEUTICS
}

\author{
Afis A. Oladosu*
}

\begin{abstract}
The author of this article addresses the issue of corruption from a perspective that exceeds the usual discussion surrounding embezzlement in corporate life and alike. Referring to the original meaning of the Arabic word for 'corruption' (al-fasād) and to its opposite al-șalāh - 'righteousness', 'accountability', 'probity' and 'piety' - he argues that talking about fasād would not make sense without addressing the issue of the 'corrupted' (mafsūd) and the 'cause for corruption' (mafsadah). In his view, proceeding from Islamic hermeneutics would be a better remedy than pure reference to 'human legislation'.
\end{abstract}

In the body is a flesh. If it is good, the whole body is good; if it is corrupt, the whole body is corrupt: it is the Heart.

The Prophet Muhammad

Just as it is impossible not to taste honey or poison that one may find at the tip of one's tongue, so it is impossible for one dealing with government funds not to taste, at least a little bit, of the King's wealth.

Kautilya, Arthashastra

\section{Introduction}

To talk about corruption - particularly in an era and in a space itself riddled with the insuperable odour of corruption - is tantamount to patronising a pastiche. That the subject matter of corruption could be likened to a palimpsest is evidenced in the sheer quantity and quality of studies it has occasioned and still does; it is evidenced in the unceasing discussions, debates, and conferences which are being organised,

* Afis A. Oladosu is Senior Lecturer at the Department of Arabic and Islamic Studies, University of Ibadan, Nigeria. At the time of writing, he has also been a Visiting Scholar at the International Islamic University Malaysia (IIUM). 
both inside and outside the academia, in the East and the West, all in an effort to plumb its inner recesses, derive reason for its 'popularity' and indeed notoriety and to account for its seeming unassailability. What other than the need to reduce incidences of corruption in human societies could have led to the publication of such studies as "Corruption: The Facts," "Does Corruption Grease or Sand the Wheels of Growth?," "Sources of Corruption: A Cross-Country Study," "Accounting for Corruption: Economic Structure, Democracy and Trade," "Corruption: A Review," "International Marketing Ethics from an Islamic Perspective: A Value-Maximisation Approach," "The Causes and Consequences of Corruption," "Balancing Ethical Responsibility among Multiple Organisational Stakeholders: The Islamic Perspective," "International Case Study: Stamping out Corruption in Malaysia,"" and "A Moral Economy of Corruption in Africa?"10 by de Sardan.

Nevertheless, de Sardan's approach is particularly useful. According to him, any attempt to engage with the scourge of corruption anywhere in the world should begin with the understanding of

the moral economy of corruption [...that] the real borderline between what is corruption and what is not fluctuates, and depends on the context and on the position of the actors involved. ${ }^{11}$

In other words, determining what constitutes corruption particularly when it is likened to honey or poison that one finds at the tip of one's tongue is a risk. The ambiguity in the nature of corruption which Kautilya's analogy hints at is actually an indirect reference to the tenuous and weak nature of contemporary political systems across the world. Embedded in that analogy which de Sardan refers to as "the moral economy of corruption" is the idea that it is practically impossible to walk straight in a world which is structurally crooked, that corruption could be likened to a crime people commit individually and/or communally either by choice, by chance or by compulsion. To hold public office nowadays is to run the risk of becoming corrupted or corruptible, of becoming the corruptee or the corruptor. Corruption has become a source of concern to economists notwithstanding the fact that it can only thrive through economic 'gymnastics'; it is a source of concern for politicians even though without it most government functionaries would never have come close to power. According to Nuhu Ribadu, the former Director of Nigeria's Anti-Corruption Agency, corruption has cost Nigeria "more than US\$380 billion since independence in 1960 and $\$ 140$ billion to sub-Sahara Africa." 12 It is probably based on these facts that corruption has become an "infernal mechanism," a field in which all have become detectives in the "crime they themselves have committed," 13 which led de Sardan to conclude as follows:

$[\ldots T]$ he development of movements of a 'puritanical' tendency, intended to bring 
about a reform of public morals (which can assume, in Islam as in Christianity, a fundamentalist hue) may be among the ultimate means, in the absence of an improbable self-reformation of the political elites, to attempt to change the present course of affairs. Any 'anti-corruption' policy must face up to these realities. ${ }^{14}$

However, in calling for a "puritanical tendency" which is capable of bringing about a "reform of public morals" such as Islam and Christianity, de Sardan appears to be working on two assumptions: one, that the solution to corruption, even though it is a human/terrestrial problem, lies only in the extraterrestrial, and two, that it is only Islam and Christianity and, perhaps, other eastern religions that can stake claims to their ability to confront the scourge.

Much as these assumptions could be appealing to the religious critic, they, however, appear to have failed to explain in detail how religion could serve or has served as an antidote to the scourge of corruption. Again while opting for Islam and Christianity as the only solution for corruption, de Sardan and indeed other pro-religious critics could be accused, at least by the non-religious critic, of taking humanity in the wrong direction, that when humanity comes face-to-face with hunger, we are saying people should proceed to the mosque or church rather than to the farm.

Thus this paper, while identifying with de Sardan's analysis of premises for corruption in human societies, intends to highlight practical steps that the religion of Islam proffers as solution to the problem. This article does not close its eyes to the incidences of corruption that have continued to occur in the contemporary world due to the involvement of the 'religious', that certain segments of the practitioners of the religion of Islam and Christianity are corrupt, corrupters, and corruptees. This article also works with the clear notion that it is not only the 'religious' that is capable of identifying corruption and punishing the corruptible. Here a reasoned attempt is made to avoid the temptation to gloss over the possibility that such 'godless' states as China are actually quite capable of recognising the evil of corruption - and in dealing too with it (violently) as it did when it executed fourteen state officials for corruptible practices in 2002. ${ }^{15}$

Thus our field of engagement becomes clear. We are confronted with the following fundamental questions: how does Islam view the government office - that is, the proverbial 'honey or poison'? If it is true that Islam could provide insights into how corruption could be combated, how then might we explain some of the role of some Muslims as corrupters and corruptees in governmental and nongovernmental circles nowadays? What arguments and claims does Islam present either for the causes, features, and impacts of the phenomenon or how could it be mitigated if not completely exterminated from human societies? 


\section{Corruption: The Linguistic Background}

In Arab-Islamic culture, things are usually known by their antithesis (al-ashyā' tu 'rafu $b i$-add $\bar{a} d i h \bar{a})$. Thus the Arabic word for 'corruption' (al-fasād), which is derived from the triliteral verb root $f-s-d$ (fasada), is according to Ibn Manzūre's lexicon Lisān al- 'arab the opposite of al-șalā $h^{16}$ which variously means 'righteousness', 'accountability', 'probity' and 'piety'. In this context, to talk about corruption, fasād would be invalid without talking about the corrupted (mafs $\bar{u} d$ ) and the cause for corruption (mafsadah) and to attempt to derive meaning from those two would be impossible in the absence of the corrupter (fäsid/fasid). Ibn Manzūr goes further to cite an example, as is usual with classical Arab culture, in which human existence is usually filtered through the prism of sexual relations. According to him, the Arabs deem corruption to have taken place when "a man engages in sexual relation with his lactating wife only for the woman to become pregnant. By becoming pregnant the woman's milk is corrupted, and the child who had hitherto not been weaned is infected by the corruption which the intercourse between the man and the lactating woman occasioned." ${ }^{17}$ In this similitude, if as such it may be called, four elements in the web of corruption become discernible: the corrupter (the husband), the corruptee (the wife), corruption (the woman's breast-milk) and the corrupted (the child). The child, in becoming the corrupted, Ibn Manzūr concludes, also becomes al-ghìlah - a demon. ${ }^{18}$

\section{Corruption: The Qur'ānic Hermeneutics}

Let us sidestep the linguistic and proceed to the qur'ānic. To talk about the qur'ānic treatment of corruption is to keep in mind the spiritual and the secular; the mystical and the profane. The word 'corruption' (fasād) or its inflected derivatives appears not less than fifty-two times in the Qur'ān. ${ }^{19}$ These verses not only mirror various trajectories of corruption as a concept, but also the features, impacts and implications of the phenomenon on human society and on the Universe. The qur'ānic engagement with corruption mirrors the quintessential Islamic doxa; it represents the template upon which Islamic perspective to the phenomenon must be premised. It also essays the Islamic perspective to the web of corruption where corruption, the corrupter, the corruptee, and the corrupted are critical elements.

Broadly speaking, two meanings could be inferred from the employment of the word 'corruption' in the Qur'ān: the spiritual (al-fasād al-rūhị) and the material (al-fas $\bar{a} d$ al-māddì). Whereas spiritual corruption cannot be subjected to scientific enquiry, material/human corruption is not only physical, but is equally heinous; whereas spiritual corruption may be precedent to the material, the Qur'ān, nonetheless, contends that the latter usually harps back to the former; material corruption usually projects and serves as reinforcement for the spiritual decay of the human psyche. 
Put differently, the more materially corrupt the human agent becomes, the faster its descent into the abyss of infantile spiritual malaise and infamy; the more its descent into the black hole of corruption the more its involvement in material corruption. Even though, in line with our suggestion above, verses of the Qur'ān that furnish insights into the dynamics and poetics of corruption in human nature, nurture and society are many, let us begin with an anecdote gleaned from the Qur'ān.

Sometime during the primordial period, angels were "invited" into the "presence" of the Almighty. God consequently informed them of His intention to create Prophet Adam (upon him be peace) - humanity. The angels, apparently basking in the knowledge endowed to them by God of the nature and destiny of humankind, voiced what could be referred to as subtle protest and disapproval of God's intention by saying:

Will you place on earth he who shall perpetrate corruption therein (yufsidu fīhā) and spill blood [...]. ${ }^{20}$

The Qur'ān informs us that whereas God's response to the angels is "I surely know that which you (the angels) do not (and would) never know,"21 the Prophet Adam, his wife, and their children soon confirm the notion of human nature that the angels had. They went against the injunction of God by eating the 'forbidden fruit' while their sons, Qābīl (Cain) and Hābīl (Abel), were in feud ending with the former killing the latter. These events, therefore, could be referred to as the beginning of the spiritualmaterial corruption on earth.

In other words, the desire in humans to perpetrate corruption, whether material or spiritual, could be said to be as old as creation. It could be likened to the proverbial forbidden fruit - the more it is prohibited, the more humanity seeks access to it; the harsher the punishment prescribed for the corrupters, the more engaging the latter's desire to commit the crime. Forbidden fruits, in line with the Arab axiom, are usually the sweetest (al-thamarat al-muhramah hulwat ${ }^{\text {th }}$ ).

However, if careful consideration is given to the nature and circumstance of human existence, and if the problematic aspect of corruption is given closer scrutiny might it not be argued that corruption is indeed an 'integral' part of the 'human edifice', that make up that part of human nature which must be discarded the same way humankind is bound to endeavour to empty its kidney of urine and the stomach of excreta? Here a risky suggestion is being proposed: that corruption may be useful after-all, not in the sense of "grease the wheel"22 argument proposed by Pierre-Guillaume Méon and Khalid Sekkat, but in its ability to serve as a yardstick with which honour and prestige may be conferred in a society. Thus corruption becomes that solemn, but subtle mystical-physical element in human existential realities which the Qur'ān refers to as al-khabith - the dreg: that element which must be distinguished, or, again, in qur'ānic parlance, sieved from al-tayyib - the pure - in order for God to confer 
celestial bliss on the faithful. Without a conscious attempt on the part of humanity to separate al-khabith from al-tayyib ${ }^{23}$ the attainment of such universal values as transparency, honesty, probity and accountability would be difficult if not outright impossible.

In other words, if righteousness (salāh) is indeed the ideal after which humanity should strive, its pursuit can only be invigorated by the flight from evil and corruption (fas $\bar{a} d)$; the search for righteousness can only become strengthened pursuant to our knowledge of the evil in the nature of evil and our preparedness to run away from it. Our thesis is this: we do the right thing by virtue of our knowledge of what is wrong; our knowledge of falsehood and evil, aside from insights bestowed on humanity by God, is precedent to the truth in our thought, speech and action. This probably explains the categorisation of humanity in the Qur'ān into three. In the first Allah says:

This is the Book in which there is no doubt. It is a guide for those who are God conscious, who believe in the Unseen, who establish Salah (five regular daily prayers) and spend in charity out of what We have provided for their sustenance, who believe in this Revelation [i.e. the Qur'ān] which is sent to you (O Muhammad) and the Revelations which were sent before you [Torah, Psalms, the Gospels...] and firmly believe in the Hereafter. They are on true Guidance from their Lord and they are the ones who will attain salvation. ${ }^{24}$

Classical qur'ānic exegetes ${ }^{25}$ agreed that the above-quoted verses image human beings who occupy the first place in the hierarchy of humanity's spiritual status in the reckoning of the Almighty. These are referred to as the 'believers': men and women who recognise Allah as the Creator and Sustainer of the universe and dedicate their lives to His worship; men and women who not only constantly struggle to be free of spiritual corruption, but equally endeavour to avoid material corruption in their private and public conducts. This group among humanity does not glory in and profess corruption even if, either by compulsion or necessity, they find themselves in corruptible spaces and circumstances.

In the second level of qur'ānic discourse of corruption, we read about, in two subsequent verses, the disbelievers. Allah says:

In fact, as for those who reject Faith; it is the same, whether you warn them or you don't, they will not believe. Allah has sealed their hearts and their hearing, their eyes are covered, and there is a grievous punishment for them. ${ }^{26}$

The disbelievers, in the light of the above, are individuals in human societies who, from the purview of the Qur'ān, are neck deep in material corruption which in itself is a direct result of their immersion in disbelief in Allah and His messengers. Here disbelief in Allah and His messengers constitute spiritual corruption on, at least, two 
levels: the primary and the secondary. At the primary level, the disbeliever becomes a corrupter of his own soul through his resolve not to acknowledge Allah as his Creator (al-khāliq), Sustainer (al-rabb), and object of worship (al-ilāh $)^{27}$ while his heart, the locus of understanding and intellection and the link between him - the disbelieverand his creator, Allah, becomes corrupted by the very act of unbelief.

At the secondary level, however, unbelief (kufr) becomes spiritual corruption in its potential at diverting the rest of humanity from the worship and adoration of God. Once spiritual corruption is realised at the primary level, once the human agent who consciously disbelieves the four elemental foundations of human existence - tawhid (unity of Allah), khiläfah (vicegerency of humanity), risälah (prophethood), and qiyāmah (resurrection) appropriates enough space, authority and status in society to manifest his unbelief, he invariably becomes a corrupter. His apparent success in life which, in the qur'ānic parlance, ${ }^{28}$ is in reality not success, but a mirage, becomes a source of spiritual infection and pollution. This is because humanity, particularly those at the fringe of spiritual-material enlightenment, would begin to wonder whether disbelief is actually not better than belief. The latter would eventually begin to move, gradually down the ladder in order to join him at his level. They would eventually become, in spiritual terms, the corrupted while the disbeliever, the agent who, despite his unbelief, is materially comfortable becomes the corruptee.

The third major level of qur'annic discourse about corruption is concerned with the portrayal of that group among humankind which occupies the space between belief and un-belief; men and women who usually posture as incorruptible elements but who, in reality, are actually the perpetrator and facilitator of corruption on earth. With reference to them Allah says:

And among mankind, there are some (hypocrites) who say: we believe in Allah and the last day while in fact they believe not. In their hearts is a disease and Allah has increased their disease; a painful torment is theirs because they used to tell lies. And when it is said to them: commit no corruption on the earth they say we are indeed the righteous ones. Verily they are the ones who make mischief but they perceive not. ${ }^{29}$

This group among humankind, which later came to be known and designated in Islam as hypocrites (al-munäfiqūn $)^{30}$ commit both types of corruption that we have identified: the spiritual and the material. Spiritual corruption occurs, in this instance, via the double identity that this group maintains:

When they meet those who believe they say "we are indeed with you", but when they repair to their cohorts they say "we are actually with you, we are only making jest of them. ${ }^{31}$

Here insight is furnished by Allah into the condition of spiritual corruption in which the hypocrites are manacled - a condition which is more heinous and dastardly 
than that in which the unbeliever is steeped. In trying to benefit both from belief and unbelief, in their resolve to occupy that spiritually odious space which Abū Hāmid al-Ghazālī (d. 1111) refers to as 'the space in-between', ${ }^{32}$ the hypocrite ironically suffers double jeopardy: he is treated as the enemy within by the Muslims; he is viewed as the fifth columnist by the unbelievers; he is a disbeliever by Allah; he is ironically seen by some unbelievers as a believer.

But in identifying with the two groups, the hypocrite succeeds in appropriating a bigger space unto himself - he becomes better able to spread as much corruption on earth as possible. According to Ibn Kathīr (d. 1373) ) $^{33}$ this group constitutes the greatest number of humankind. In their 'majority' status we probably have explanations for the 'web' of corruption and the seeming intractability of the problem in the world today. The ascension of members of this group to position of authority be it political, economic, or religious - usually leads to the increment in the incidences of corruption on earth.

\section{The Web of Corruption}

The point at issue above is this: each time humanity bewails the insuperable and pervasive odour of material corruption, it is indirectly lamenting the ascendancy of the spiritually corrupt to the top echelons of power; the ascendancy of a leadership which is not only incapable of differentiating between, according to Seyyed Hossein Nasr (b. 1933), "the axis and the rim of existence", ${ }^{34}$ but also unable to properly and correctly position both "the axis and the rim" of life where they should belong. In other words, by putting the 'rim' in front, the 'axis', by giving preference to the transient over the permanent, by emphasising the mundane over the spiritual, corruption becomes a categorical imperative. It is this misplacement of priority in life which explains the unbridled lust for wealth and position by humankind and the consequent prevalence of corrupt practices in human societies. Thus, once authority is appropriated by the spiritually corrupt - an authority which considers itself to be accountable and inferior only to itself - the path becomes automatically clear for the perpetration of all evils. Abū 'l-A 'lā Mawdūdī (d. 1979) puts this in sharper perspective when he queries:

Can a person having no fear of God and with no realisation of the retribution of the Day of Judgment be restrained from indulging in dishonest acts and irresponsible behaviour? Can a person thus bereft of all vestiges of loyalties except the one for his individual self be persuaded to sacrifice his personal gains? Only loyalty to lofty ideas moves a man to sacrifice, and for a Muslim, there is no basic loyalty higher than his loyalty to his God, to the Holy prophet and to the Muslim nation. If this loyalty gets shaken, the natural consequences will be [the] emergence of selfish and mean preferences in all hideous forms..$^{35}$ 
Thus what is popularly known in the world today as corruption or al-fasād al$m \bar{a} d \bar{\imath}$ (material corruption) which includes "the abuse of public power for private benefit;" "36 "any induced behaviour with the primary aim of falsifying the outcome of the behaviour to the benefit of the inducer;",37 "the act or state of corrupting or being corrupt or dishonest" ${ }^{\prime 38}$ are all products of a more heinous variant of corruption, namely spiritual corruption. Material corruption is often reinforced by such other factors as "dysfunctional civil service regulations, defective bureaucracy, low salaries and wages, weak punishment or penalty systems and non-transparent rules, laws and processes." ${ }^{39}$ Material corruption also thrives as a result of "over-regulation of private activity; expanded public sector economy; expanded public sector procurement and weakened scrutiny." 40

Even though the 'web' of corruption, like that of the spider, should ordinarily be weak, experience has, however, shown that it usually gains strength through the prevalence of poverty and deliberate impoverishment of the masses. The 'web' of corruption equally gains strength through the patronage of scholars and 'men and women' of God. In other words, corruption usually produces its own intellectuals who, in turn, produce what may be described as the discourse of corruption. The discourse of corruption is often enamoured by religious scholars and "ulamä"s advise to the people to "listen and obey' ${ }^{41}$ corrupt despots as long as they are allowed to pray. When scholars put their learning and revered position to the service of corruption and corrupters, we witness what is known in Latin as corruptio optimi persima ${ }^{42}-$ 'corruption of the best which is the worst form of corruption'. Such scholars become perpetrators of double corruption: the corruption which they bring to bear on the divine text by their act of deliberate misinterpretation and that which occurs as a result of their acquiescence to, silence and apparent refusal to guide or steer the political class along that path where corruption would not only be difficult, but impossible.

\section{Confronting Corruption in Islamic Hermeneutics}

How might we begin to explore anti-corruption writs in Islam? Two pathways may be available for us to tread: the preventive and the curative. The following verses of the Qur'ān which contain what we would refer to as the nine commandments are highly germane to preventive precepts established by God for humanity against corruption:

Say! 'come, I will rehearse what Allah has prohibited you from: Join not anything as equal with Him; be good to your [parents; kill not your children on plea of want - we provide sustenance for you and for them; come not nigh to shameful deeds, whether open or secret; take not life which Allah has made sacred, except by way of justice and law; thus He commands you so that you may learn wisdom. [...] And come not nigh to the orphan's property, except to improve it, until he attains the 
age of maturity; give measure and weight with full justices - no burden do we place on any soul, but that which it can bear; whenever you speak, speak justly even if a near relative is concerned; and fulfil the covenant of Allah thus He commands you so that you may remember $\mathrm{Him}[\ldots],{ }^{43}$

In the above verses, we are reminded that any attempt to prevent corruption on earth must begin with the realisation that the problem, as we have attempted to do above, is not only and simply material, but spiritual; that corruption could manifest itself at the intrapersonal, interpersonal and communal levels. What Islam therefore does is to lay down the rules which the believer is expected to abide by. The rules, elements or virtues which may be divided into 'dos' and 'don'ts' are evident from the above verse. The 'to do' divinely ordained virtues include: belief in God, goodness to parents, giving full measure, and speaking justly, while 'don'ts' include infanticide and all other shameful deeds, including murder and embezzlement.

A careful contemplation of these virtues would reveal that they constitute important parameters both for the measurement of the incidences of corruption on earth even as they speak to the identities of the corrupters and the corruptees in human societies. For example, it is consensual to view the employment of bad measurement in the market-place and the embezzlement of public fund as acts of corruption. In the latter, the marketers and politicians who indulge in the act not only corrupt the market and the political system through their unholy acts, but equally corrupt their personal spiritual well-being. Again, the marketer or politician who engages in corruptible practices might probably not be involved in the act had it been the case that he chose to work in line with the 'shame theory' that is mentioned in this verse.

In other words, when Allah says "come not nigh to shameful deeds" attention is being called to the fact that one of the identities of the corrupter is a person who lacks modesty; he is the rational being who is willing to engage in an act which the lower animals would ordinary not engage in. The corruptible person is the subject who could go naked in the market even though nakedness is antithetical to his physiology and destiny. The Qur'ān therefore desires to keep humankind within the purview of its destiny: an honoured and ennobled creature - a vicegerent of the creator of the worlds through the provision of these basic virtues and anti-corruption elements.

The preventive ethos established by Islam against corruption might also include the fact that Islam views the occupation of a position of authority, and in fact the whole gamut of human existence, as a test for which the believer shall be held to account on the Day of Resurrection. To be a head of state or the permanent secretary, for example, therefore, is to occupy a position of trust (amānah). In order to prevent or at worst reduce the possibility of corruption in public offices, Islam, therefore, enjoins the Muslims to entrust the position to the most spiritually and morally qualified. Failure to do this is to risk socio-economic and political anomie. The Prophet Muhammad emphasised the importance of appointing the right people in positions of authority when he says: 
Whoever delegates a position to someone whereas he sees someone else (who is more qualified), verily he has cheated Allah and His apostle and all the Muslims. ${ }^{44}$

The Prophet is equally reported to have said:

Each of one of you is a shepherd and each one is responsible for the flock under him. ${ }^{45}$

Let us now assume that the morally and spiritually qualified has been given authority, how does Islam grapple with the fact that power often becomes a 'honey' at the tip of the tongue of the statesman? How does Islam ensure that the powerful not become inebriated and hostage to the entrapments of power? The answer to this question might be found in the character of the persons concerned as to whether their moral and spiritual life is deeply rooted in the teachings of Islam. This is because insights abound in Islamic history of the possibility of that scenario in which one may find the 'honey' of power on one's tongue without taking more than the law permits. This is particularly the case with the second caliph 'Umar b. al-Khațāa (r. 634-44) who once saw a very lean and thin young girl. He said: "What a sad plight the child is." ${ }^{6} \mathrm{He}$ soon got to know that the girl was actually his granddaughter. Then 'Abd-Allāh, his son, told him: "whatever is in your charge you give us nothing from it $[\ldots]$ this has brought her this sorry state." 47 'Umar then said:

By God, I have nothing for you more than I can give out to the believers in general, whether it meets your need or not. The book of God stands to decide between us. ${ }^{48}$

Here 'Umar's statement and conduct not only portrays him as incorruptible, but also one who is unwilling to allow corruption fester within the Muslim polity. By refusing to give to his family more than the law provides, he also keeps in view the possibility that power and authority could indeed be honey and poison at the same. He had the serenity of mind not to succumb to temptation; he was sufficiently conscious of the implication of such an action on his spiritual status and the welfare of the State. Thus his action feeds the suggestion that consciousness of the existence of God is the only armour against the most tempting of all temptations.

'Umar's conduct also emphasises the importance of such elements as justice ('adl), equity (qist) and benevolence (ihssān) as critical elements in the appropriation of Islamic hermeneutical treatment of corruption. The Prophet of Islam is reported to have said that among the inhabitants of Paradise will be:

[...] one who wields authority and is just and fair; one who is truthful and has been endowed with power to do good deeds; and the person who is merciful and kindhearted towards his relatives and to every pious Muslim, and who does not stretch out his hand in spite of having a large family to support. ${ }^{49}$ 
In contrasting the concepts of $i h s \bar{a} n$ and 'adl, al-Qurțubī (d. 1273) argues that when Allah says "Lo! God enjoins justice and kindness" mandatory while ihsān (benevolence) is what is above and beyond the mandatory. Quoting Sufyān b. 'Uyaynah, al-Qurțubī states further that "'adl means that the person's inner intentions and feelings should be consistent with his/her declared words and actions, while ihsān means that the person's inner intentions and feelings are even better than his/her words and actions." ${ }^{51}$ The word $i h s \bar{a} n$, which is derived from the Arabic root $h-s-n$, refers to any act that is deemed 'suitable', 'beautiful,', 'proper', or 'fitting'. It operates at the core of Islamic ethics. ${ }^{52}$ The Muslim subject in authority who works with these ideals would neither be corrupt despite the sweet taste of the 'honey' in its tongue nor would he be a corrupter. He would conduct himself with the full consciousness that God watches over all things even if the citizens or the law are, as it is, absent. Allah says again:

Because of that we ordained for the children of Israel that if anyone killed a person not in retaliation of murder or spread corruption on earth - it is as if he killed all mankind, and if anyone saved a life, it would be as if he saved the life of all mankind $[\ldots]^{53}$

This verse thus appears to bring closure, not conclusion, to the discussion of how Islam seeks to prevent the incidences of corruption in the world. Here we are informed that Allah abhors corruption to such an extent that its perpetrators are promised terrestrial and eschatological retribution. By employing the connective, $k a$ annama ('it is as if') in the above verse, the act of corruption is equally divested of geographical or racial identity. An act of corruption committed in Africa is therefore deemed to have multiple and grave implications for the wellbeing of humankind in Asia; the corrupter who goes scot-free in America becomes a threat to humanity in Malaysia. Whereas they may or may not be caught while on earth, the above verse seeks to establish the impossibility of escape for the corrupter from divine wrath and to warn human beings from committing all acts that may be deemed corruptible. The above verse also seeks to affirm, as we have proposed above, that for every material corruption perpetrated on earth, there are spiritual implications.

In talking about the Islamic ethos which could serve as curative measures against corruption, Ibn Qayyim al-Jawzīyyah's (d. 1350) ideas are very useful. In his opinion, any attempt to eradicate al-fasād (corruption) from human societies would always be confronted by four possibilities:

1. total eradication of corruption in which case its opposite (righteousness, accountability, honesty) comes into being,

2. minimisation of corruption even if it cannot be completely eradicated,

3. substitution of corruption with something similar, and

4. substitution of corruption with something worse and greater. ${ }^{54}$ 
Whereas possibilities four and three do not enjoy any patronage in Islamic law and jurisprudence, two and one, on the other hand, fall within the ideals that Islam has set for humankind. In fact, the ideal state in Islam is that in which corruption is completely eradicated. It is that which is eulogised by Allah when He says:

Those when they are established on earth establish prayers and give out alms, enjoin that which is good and forbid that which is wrong $[\ldots]^{55}$

However given its natural imperfection, it is often not the case that corruption may be completely eradicated from human societies. This invariably leads to the strong Islamic ideal that Muslims should constantly rise against corruption and corruptible tendencies in the world. In fact not doing this is to risk divine damnation:

Those of the children of Israel who went astray were cursed by the tongue of David, and of Jesus, son of Mary. That was because they rebelled and used to transgress. They restrained not one another from the wickedness they did. Verily evil was that they used to do! ${ }^{56}$

The Prophet of Islam is reported to have said:

He who amongst you sees an evil should change it with the help of his hand; and if he has not strength enough to do it, then he should do it with his tongue, and if he has not strength enough to do it, (even) then he should do it with his heart, and that is the least (sign) of faith. ${ }^{57}$

He is equally reported to have warned thus:

Should it occur that the people of my community (ummah) have such extreme fear that they become unable to say to the unjust people 'You are wrong', they would no longer be worthy of life. ${ }^{58}$

It is in keeping with this injunction that societies that more or less 'fully' operate Islamic law (sharī'ah) usually establish an agency known as the hisbah. ${ }^{59}$ The hisbah's main task is that of maintaining public order and decorum. The muhtasib, the official in charge of the hisbah, al-Māwārdī (d. 1058) opined, not only assists the authorities in enjoining good conduct, it is equally part of his mandate to prevent the spread of corruption and the punishment of the corrupt in society. ${ }^{60}$

One other option which is evident in Islamic history for the extermination of corruption is the increment in material provision for the masses. A case in point, in this instance, is that of the Umayyad caliph 'Umar (II) b. 'Abd al-'Azīz (r. 717-20). ${ }^{61}$ It was during his reign that the Muslim community became so prosperous that only the tax-payer remained in the polity; there remained no tax-receiver. He therefore gave instruction for tax distributors to travel round the caliphate in search of tax- 
receivers, but tried as they did, they could not come across a citizen of the caliphate who would take the alms. Thus the Islamic perspective to a corruption-free society is hinged not only on the nexus between the divine and the creatures, but equally on the promotion of public wealth and prosperity. It is in line with this philosophy that Islam demands the payment of a regime of wages that will not only make the employees of the state 'exist', but 'live' a descent life. This ideal operates at the core of the Islamic concept of an egalitarian society. The ideal serves both the preventive and curative functions in any attempt at confronting the scourge of corruption in the world today.

However, there remains one other Islamic writ that must be mentioned: the institution of stiff punishments to deter the perpetration of corruption. The following qur'ānic verse reads:

The only reward of those who make war upon Allah and His messenger and strive after corruption in the land will be that they will be killed or crucified or have their hands and feet on alternate sides cut off or will be expelled out of the land. Such will be their degradation in the world, and in the Hereafter theirs will be an awful doom. ${ }^{62}$

Here Allah calls attention to the fact that one of the best ways to cure societies of its heinous crimes is the application of punishments that would not only deter the commission of such crimes, but would equally render the criminal incapable of returning to the commission of such crimes in future. Studies on corruption trends across the world has shown that the milder the punishment against corruption the more its perpetration, and the harsher the punishment the less the temptation to commit it. ${ }^{63}$ In applying punishment against corruption, Islam would insist on equity and justice - that no member of the society should be treated differently from the rest of the society no matter his/her status.

\section{Conclusion and Recommendations}

In closing, I wish to return to the question which I raised above, but which I deliberately side-stepped: if it is true that Islam abhors corruption, how do we explain the involvement of Muslims in the scourge? In answering I would ask another question: how do we explain the commission of a sin by the Prophet Adam against which he had previously been forewarned ${ }^{64}$ Questions like this not only mirror the trajectories in the Weltanschauung of Muslims, but equally the poetics of corruption in Islamic hermeneutics.

- The involvement of some Muslims in acts of corruption essays the disconnection between Islam in the text and the Islam in the context of existential realities of Muslim societies across the world. 
- When laws promulgated by authorities, including the divine, are blatantly broken by humankind, the latter, in line with the Qur'ān, should be prepared for "a war from the Almighty Allah." 65

\section{Notes}

1. Daniel Kaufmann, “Corruption: The Facts," Foreign Policy 107 (Summer 1997), 114-31.

2. M. Pierre-Guillaume and K. Sekkat, "Does Corruption Grease or Sand the Wheels of Growth?" Public Choice 122, no. 1-2 (2005), 69-97.

3. Gabriella R. Montinola and Robert W. Jackman, "Sources of Corruption: A Cross-Country Study," British Journal of Political Science 32, no. 1 (January 2002), 147-70.

4. W. Sandholtz and W. Koetzle, "Accounting for Corruption: Economic Structure, Democracy and Trade," International Studies Quarterly 44 (2000), 31-50.

5. J. G. Lambsdorff, “Corruption: A Review,” Journal of Economic Surveys 15 (2003), 71-121.

6. M. Saeed, Z. Ahmed, and M. Syeda-Masooda, "International Marketing Ethics from an Islamic Perspective: A Value-Maximisation Approach," Journal of Business Ethics 10 (2008), 127-42.

7. A. Omar, L. Young, and S. Anand, "The Causes and Consequences of Corruption Author," Annals of the American Academy of Political and Social Science 573 (2001), 42-56.

8. I. Beekun Rafik and J. Badawi, "Balancing Ethical Responsibility among Multiple Organisational Stakeholders: The Islamic Perspective," Journal of Business Ethics 60, no. 2 (2005), 131-45.

9. Tunku Abdul Aziz, "International Case Study: Stamping Out Corruption in Malaysia," Resource Material Series [UNAFEI, Tokyo, Japan] 56 (December 2000), 393-98. On the scourge of corruption in Asian countries at large see also Syed Hussein Alatas, The Problem of Corruption (Singapore: Times Book International, 1986).

10. J. P. Olivier de Sardan, "A Moral Economy of Corruption in Africa?" Journal of Modern African Studies 17, no. 1 (1999), 25-52.

11. Ibid., 34.

12. Washington Post, 20 May 2009; for more on those issues, particularly as they affect the corruption index in Nigeria, see T. B. Solomon, "Corruption as a Perennial Culture and its Repercussions on Nigeria," in: R. A Raji et al. (eds.), Religion, Governance and Development in the $21^{\text {st }}$ Century (Ilorin [Nigeria]; Decency Printers and Nigerian Association for the Study of Religions (NASR), 2006), 15.

13. R. C. Collingwood, The Idea of History: 1926-1928 (Oxford: Oxford University Press, 1994), 269.

14. de Sardan, "A Moral Economy," 30.

15. On the harsh Chinese punishments for corruption see B. Bakken, Crime, Punishment, and Policing in China (Lanham MD: Rowman and Littlefield Publishers, 2004).

16. Ibn Manẓūr, Lisān al- 'arab (Beirut: Dār al-Kutub al-'Ilmiyyah, 2009), 3411.

17. Ibid., 3412 .

18. Ibid.

19. For more on the treatment of this and other ethical constructs in Islam see T. Isutzu, EthicoReligious Concepts in the Qur'an (Montreal: McGill University Press, 2002).

20. Qur'ān 2:30.

21. Ibid.

22. Pierre-Guillaume and Sekkat, "Does Corruption."

23. Qur'ān 8:38.

24. Ibid., 2:2-5.

25. This is with reference to a reading of the exegeses of the Qur'ān by Ibn Kathīr, al-Qurțubī, or al- 
Suyūțī's al-Itqān.

26. Qur'ān 2:6-7.

27. This is with reference to basic principles which undergird the Islamic faith.

28. This is with reference to Qur'ān 23:57 where Allah says: "Do they [i.e. the unbelievers] think that, in giving them wealth and children, We are eager for their welfare? By no means! They do not understand the reality of the matter."

29. Qur'ān 2:6-10.

30. Many chapters and verses of the Qur'ān are dedicated to the portrayal of the persona of the hypocrite; for example see Qur'ān chapter 63.

31. Qur'ān 2:6-10.

32. Ebrahim Moosa, Al-Ghazali and the Poetics of Imagination (Chapel Hill NC and London: University of North Carolina Press, 2005), 111.

33. For an explication of this verse refer to Tafsìr Ibn Kathīr.

34. Seyyed Hossein Nasr, Islam and the Plight of Modern Man (Chicago: Kazi Publications, 2001), 4.

35. A. Mawdudi, The Role of Muslim Students in the Reconstruction of the Islamic World (Aligarh [India]: Students Islamic Movement of India, 1977), 24-25.

36. Montinola and Jackman, "Sources."

37. I. B. Bello-Imam, The War Against Corruption: Problem and Prospects (Ibadan [Nigeria]: Lead City University Press, 2005), 18.

38. Ibid.

39. Solomon, "Corruption," 15.

40. P. Collier, "How to Reduce Corruption," African Development Review 12, no. 2 (2000), 191-205; see also L. Lawson, "The Politics of Anti-Corruption Reform in Africa," Journal of Modern African Studies 47 (2009), 73-100.

41. On the role of the 'ulamā' in fighting or promoting corruption in Islamic history see Beekun Rafik and J. Badawi, "Balancing," 131-45, and J. Crystal, "Islam and Human Rights: Tradition and Politics," World Politics 46, no. 2 (1994), 262.

42. An equivalent Arabic axiom for this goes thus: lā yu'aththir al-fasād fì 'l-samak illā min al-ra's, meaning 'corruption does not impact the fish except from the head'.

43. Qur’ān 6:151-52.

44. Cited in Beekun Rafik and J. Badawi, "Balancing," 137.

45. Ibid.

46. For more on this see M. Siba'i, Some Glittering Aspects of the Islamic Civilisation (Beirut: The Holy Qur'an Publishing House, 1984), 41.

47. Ibid.

48. Ibid.

49. Reported by 'Iyād b. Hịmar, Șahīh Muslim, hadīth no. 6,853.

50. Qur'ān 16:90.

51. Abū 'Abd-Allāh al-Qurțubī, al-Jāmi ' li-ahkām al-qur'ān (Beirut: Dār al-Ihyā al-Turath al- 'Arabī, 1966), 16:90, quoted by Beekun and Badawi, "Balancing," 137.

52. Ibid.

53. Qur'ān 5:35.

54. Muhammad b. Abī Bakr b. Qayyim al-Jawziyyah, I' lām al-muwaqqi ìn 'an rabb al-'älamìn (Beirut: Dār al-J̄̄l, 1973), 10.

55. Qur'ān 24:32.

56. Ibid., 5:78-79.

57. Hadīth no. 34, al-Nawawī’s collection, in Sahīh Muslim.

58. Ibid. 
59. The word al-hisbah (or al-kifäyah) is not mentioned in the Qur'ān. Muslim jurists usually employ the word in reference to those charged with the responsibility of enjoining good conduct, particularly in market-affairs. The person in charge of such affairs is sometimes designated as al-muhtasib. It replaced the original designation of that office which was șăhib al-sīq (market supervisor). For more on this see al-Ab Khristiyānfan, "Qānūn al-ḥisbah al-jadīd fì Miṣr: Madlūluhā wa ițāruhā alta'rīkhiyyah," al-Mashriq 1 (1997), 135.

60. For qualities expected in the muhtasib see Abū 'l-Ḥasan 'Alī b. Muḥammad al-Māwardī, alAhkam al-Sultaniyyah: The Laws of Islamic Governance, transl. Asadullah Yate (London: Ta Ha Publishers, 1996), 337.

61. Siba'i, Some Glittering Aspects, 80.

62. Qur'ān 5:32.

63. Afis A. Oladosu, "Critical Perspectives to the Penal Code," in: M. O. Abdul Rahman (ed.), Perspectives in Islamic Law and Jurisprudence (Ibadan [Nigeria]: Polygraphs, 2001), 180-225.

64. Qur'ān 2:32.

65. Ibid., 2:280. 